\title{
Human Activities Impact Assessment and its Mapping in Sharyn Gol River Basin
}

\author{
Unurnyam Jugnee ${ }^{1, *}$, Bolormaa Tsooj ${ }^{1}$ \\ ${ }^{1}$ Institute of Geography and Geoecology, Mongolian Academy of Sciences, Ulaanbaatar, Mongolia \\ *Corresponding author. Email: unurnyamj@mas.ac.mn
}

\begin{abstract}
The environment condition in the central economic region of Mongolia has been degrading due to overgrazing, legal and illegal mining, arable land, expansion of settlement areas, migration to cities from rural areas, population growth. Determining the intensity and spatial distribution of the human impact activities on environment is important to plan and implement suitable protection, rehabilitation, and monitoring measures. The aim of this research is assessing the impact of human activities in the Sharyn Gol River Basin located in the central economic region of Mongolia and identifying and mapping the spatial distribution of the impact. The Human Footprint method, Geography Information System based Multi Criteria decision analysis (GIS based MCDA) and Analytic Hierarchy Process (AHP) were used to assess and the map human activities impact. Five categories of data (herders' seasonal location, dirt road distribution, settlement area, mining and agriculture land) were selected for this study. The data were obtained from Google Earth Pro and Landsat OLI imagery. Impact assessment was conducted for each type of the land use in order to create impact layers. After calculating the weight of each impact layer by GIS based MCDA and AHP method, the impact map of human activities was created by combining the impact layers. Sharyn Gol River Basin's human impact assessment estimated 4267.23 ha is severely, 20396.33 ha is strong, 55148.35 ha is moderate, 97060.18 ha is weak, and 117489.57 ha is very weak. Considering the spatial distribution of human impacts, the highest impacts are in settlement area with high density of dirt roads, mining areas, agricultural lands, and pasture area along the river valleys. The results of the human activities impact assessment and mapping study in the Sharyn Gol River Basin can be used as a reference material to plan and ensure the implementation of Government policies and decisions.
\end{abstract}

\section{Keywords: Land use, human activity impact, Sharyn Gol River Basin}

\section{INTRODUCTION}

Human society has exerted its impact on the environment through the use of natural resources since its formation. Negative ecological consequences occurr as the human impact activities on the environment increases. The environment condition in the central region of Mongolia has been degrading due to the global climate change, use of natural resources, mining, poor management and agricultural economic activities [1]. Therefore, it is necessary to determine the spatial distribution of the human impact activities which degrade environment. It is also important to plan and implement suitable protection, rehabilitation, and monitoring measures.

Research trend to assess and map human impacts began in the late 1980s, and number of human impacts assessment methods have been developed. The Human
Footprint method is widely used among these methods [2]. For instance, Human Footprint method used for biodiversity conservation [3], nature conservation management plan's implementation assessment [4], to study the migration of terrestrial mammals [5], human activities impact and species extinction risk relation [6]. Whereas, in Mongolia Human Footprint method used to assess the ecological capacity of the landscape [7], land degradation and desertification assessment [8; 9], to develop a scientific basis for environmental protection and proper planning of economic development policy $[10 ; 11]$.

Different types of land use developed in Sharyn Gol River Basin area. In one hand, this relates with relatively dense population due to favorable socioeconomic conditions, easy access to social services, closeness to markets for selling the products, and welldeveloped infrastructure. Pastureland is declining year 
by year but the number of grazing livestock and the area of arable land are increasing. In addition, unsupervised dirt roads and mining production is increasing too. Especially, gold mining in upper stream of Sharyn Gol and Khutenii river area human impact is increasing due to mining activities. Determining the intensity and spatial distribution of the human impact activities on environment is important for decreasing the impact range and defining sustainable natural use approaches. The aim of this research is assessing the impact of human activities in the Sharyn Gol River Basin and identifying and mapping the spatial distribution of the impact. In addition, the results of the human activities impact assessment and mapping study developed in the Sharyn Gol River Basin based can be used as a reference material to plan and implement the relevant provisions of the Law of Mongolia "On Agriculture" on the development of intensive livestock production in agricultural regions, and to ensure the implementation of the Order No. 131 of the Government of Mongolia dated May 16, 2018 "On Defining Some Crop Regions". Also our research findings can be used for ecological studies such as land degradation and desertification as a reference material.

\section{STUDY AREA}

The study area covers Central economic region in terms of administrative division such as Darkhan-Uul province's Orkhon, Sharyn Gol and Khongor soums and Selenge province's Bayangol, Javkhlant, Yeruu and Mandal soum area. Sharyn Gol River Basin covers $2943.61 \mathrm{~km}^{2}$, or $0.19 \%$ of the total territory of Mongolia (Figure 1).

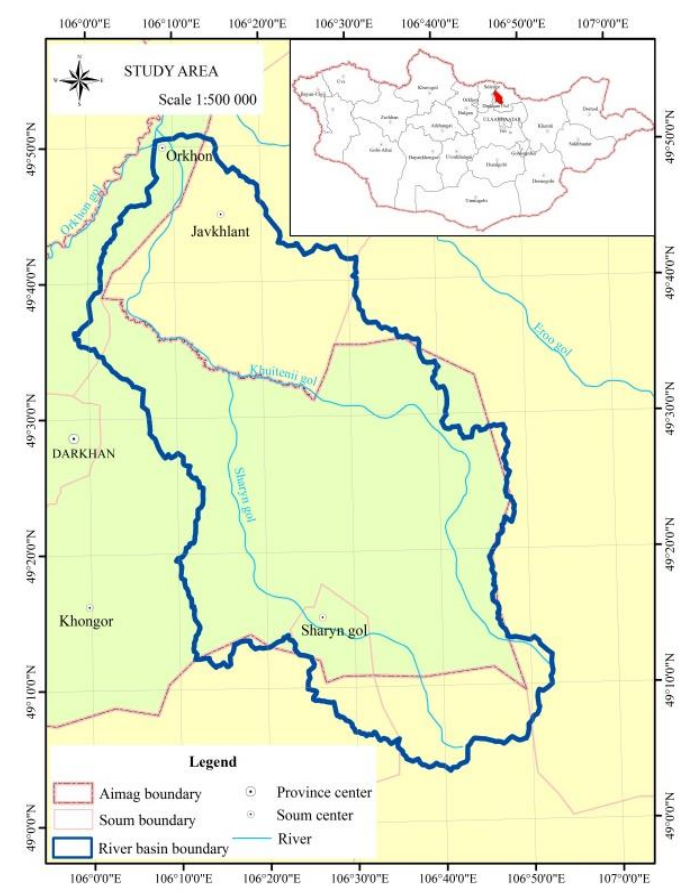

Figure 1. Geographical location of the study area

\section{METHOD AND DATA}

\subsection{Method}

Pasture utilization impact assessed based on herder household's seasonal location. According to Gunin et al. [12], winter-spring land impacts are considered to be strongly affected within $0.2 \mathrm{~km}$ of winter camps, moderately affected within $1 \mathrm{~km}$, and weakly affected within $3 \mathrm{~km}$. The impact of summer-autumn pasture use was estimated by determining the overlap of summerautumn pasture land. Pasture overlap was estimated by taking the grazing radius of small cattle during the summer with $3 \mathrm{~km}$ grazing distance [13]. Pasture overlaps value classified by using Natural Breaks Jenks method of ArcGIS software. In this method, overlapping areas of 1-4 households are considered very weak, overlapping areas of 5-10 households are considered weakly affected by pastures, overlapping areas of 11-15 households are considered moderately affected by overgrazing and overlapping areas of more than 15 households are considered strongly affected pastures.

Areas that are used throughout the year (pastures with a radius of $1 \mathrm{~km}$ for winter camps which overlap with pastures with a radius of $1 \mathrm{~km}$ for summer camps) are considered strongly affected by pasture use. Based on the Heiner et al [10] methodology, the impact of the settlement calculated by drawing a buffer zone of $5 \mathrm{~km}$ at a distance of $1 \mathrm{~km}$ from the settlement area. Crop land impact assessed strong since the landscape completely transforms and becomes an agro-landscape no matter what agro-technical methods are used [14]. The mining industry has a strong impact on the environment in many ways. The impact of mining is estimated as strong depending on the mining area. Transportation impact on land estimated based on dirt road density. The length of the dirt road calculated by creating a $1 \mathrm{~km}$ grid across the study area. A total of 3126 nets with an area of $1 \mathrm{~km}^{2}$ were generated in the study area and the values of the path lengths corresponding to the nets were classified into 4 classes using Natural breaks Jenks classification method of the ArcGIS software. The length of dirt roads per $1 \mathrm{~km}^{2}$ is very weak in 0-499 m, weak in 500-1500 m, moderate in 1501-2500 $\mathrm{m}$, and strong above $2501 \mathrm{~m}$. Human impact score ranging from 1 to 4 were assigned to each impact layer. We assigned the highest score to the strongly affected area and the lowest score to the very weakly affected area.

GIS based MCDA and AHP method used to analyze the impact layers of each type of land use and to produce an integrated map of human impacts. Human impact map developed after combining impact layers and analyzing the weights of the indicators (impact layers developed for each type of land use) using the Analytic hierarchy process. The values of human activity impact in raster image pixels were classified 
into 5 classes by ArcGIS software's Natural breaks Jenks classification: severely affected, strongly affected, moderately affected, weakly affected, and very weakly affected.

\subsection{Data}

Vector data of seasonal location of herders, distribution of dirt roads, raster data of settlements, mining and agriculture lands, unified land fund statistics and livestock statistics used for the assessment and mapping of the human activities impact (Table 1).
Pasture use (herder households' seasonal location) and distribution of unpaved roads layers were created by digitization of Google Earth Pro. Crop land, mining and settlement area's layers based on land use and land cover map of Sharyn Gol River Basin developed by "Monitoring and research of high risk rivers under human activities- Sharyn Gol River Basin” (2018-2021) basic study report. The land use and land cover map of Sharyn Gol River Basin developed by using Landsat OLI imageries (from June to August in 2018) using Maximum Likelihood Classification method.

Table 1. Data materials used for the study

\begin{tabular}{|c|c|c|}
\hline Data & Data type & Source \\
\hline Herder households' location & Vector (point) data & \multirow{2}{*}{ Obtained from Google Earth Pro map. } \\
\hline Dirt road & Vector (line) data & \\
\hline Mining & Raster data & \multirow{3}{*}{$\begin{array}{l}\text { Extracted from the Land use and land cover map of Sharyn } \\
\text { Gol River Basin, generated from Landsat OLI imagery. }\end{array}$} \\
\hline Crop land & Raster data & \\
\hline Settlement area & Raster data & \\
\hline Unified land fund data & Statistical data & $\begin{array}{l}\text { Obtained from the Agency for Land Administration and } \\
\text { Management, Geodesy and Cartography. }\end{array}$ \\
\hline Livestock number & Statistical data & Obtained from the National Statistics Office of Mongolia. \\
\hline
\end{tabular}

\section{RESULTS AND DISCUSSION}

Impact assessment was conducted for each type of the land use in order to assess the impact of human activities in the Sharyn Gol basin and to determine the spatial distribution.
Pasture is the basis of the livestock sector and is used as a major resource for production. According to the 2010-2019 land census and statistics, the amount of pastureland in the soums of the Sharyn Gol River Basin has been declining year by year, while the number of livestock grazing in that pasture has been increasing (Table 2).

Table 2. Pasture land area and livestock number change

\begin{tabular}{|c|c|c|c|c|c|c|}
\hline \multirow{2}{*}{ Soums } & \multicolumn{3}{|c|}{ Pasture land area (thousand ha) } & \multicolumn{3}{|c|}{ Livestock number (thousand head animal) } \\
\hline & 2010 & 2019 & Change & 2010 & 2019 & Change \\
\hline Javkhlant & 73.63 & 73.44 & -0.19 & 81.72 & 95.41 & 13.69 \\
\hline Khongor & 138.37 & 136.18 & -2.19 & 104 & 191.54 & 87.54 \\
\hline Orkhon & 34.66 & 33.70 & -0.96 & 33.53 & 46.22 & 12.69 \\
\hline Sharyngol & 4.82 & 4.38 & -0.44 & 37.06 & 33.02 & -4.041 \\
\hline Total & 251.48 & 247.7 & -3.78 & 256.31 & 366.19 & 109.88 \\
\hline
\end{tabular}

Total of 382 winter-spring and 370 summer-autumn locations were identified and the impact of winterspring and summer-autumn pasture use estimated within the study area based on this location. Pasture use of winter and spring lands is affected by $64 \%$ or 188507.9 ha from the total area of the Sharyn Gol basin (Figure 2). Total of $45 \%$ of the basin area is affected by the summer autumn pasture use. Sharyn gol valley and Khuitnii goliin valley's used for summer autumn pasture grazing. The highest overlap of the summer autumn pasture grazing determined in Sharyn gol valley, Khuitnii gol valley, Argal uul, Sharyn tsagaan lake, Dardan lake, Uushig mountain, Khushuut khoshuu, Ulaan shoroot valley and Bunkhan tolgoi area. Especially, in Argal mountain area up to 25 househols' animal pasture overlaps (Figure 3). Total of 17323 ha pastureland area in the basin is re-used throughout the year and is severely affected by pasture users. In other words, due to the decreased number of movement among herder households in winter camp area $(1 \mathrm{~km}$ radius from the winter camp) total of 17323 ha pasture over used throughout the seasons. Mostly the river valleys are overused for grazing through the year (Figure 4). Winter spring camp pasture and crop land overlaps are high in this area. Mongolian Law on Agriculture prohibits grazing on farmland within $500 \mathrm{~m}$ of the edge of the farm including winter, spring, and summer camps. However, there are 92 winter-spring camps under this law in study area.

A total of 17565.98 ha of arable land was identified in the study area and 17369 ha or $98.8 \%$ overlaps with winter-spring pasture land. The overlap of winter and spring pastures and arable land at the distance from the winter camp, the overlap with the winter area with a radius of $1 \mathrm{~km}$ is 5461 ha and the overlap with the winter area with a radius of $3 \mathrm{~km}$ is 11908 ha (Figure 5). 
Sharyn Gol river basin crosses the territory of seven soums in two aimags and the Orkhon, Javkhlant, and Shariin Gol soum centers are located within the basin boundary. Total of $6.18 \%$ of the total basin area is affected by the settlement (Figure 6). The mining impact estimated in Sharyn Gol open pit mine and the placer gold mining area where it's operated and operating in the upper stream of the Sharyn Gol and Khuitenriver. A total of 3658.83 ha of land was affected by mining (Figure 7). A total of $1659.68 \mathrm{~km}$ of unpaved roads identified in the Sharyn Gol river basin which covering a total area of 995.81 ha. This indicates that there are many unpaved roads in rural areas. Total of 130015.38 ha of land was affected by unpaved roads (Figure 8). The size of the impacted area for each type of land use is as follows (Table 3).

Table 3. The size of the impacted area

\begin{tabular}{|l|l|l|l|l|}
\hline \multirow{2}{*}{\multicolumn{1}{c|}{ Impact }} & \multicolumn{4}{c|}{ Affected land area (by ha) } \\
\cline { 2 - 5 } & \multicolumn{1}{c|}{ Strong } & \multicolumn{1}{c|}{ Moderate } & \multicolumn{1}{c|}{ Weak } & Very weak \\
\hline Winter-spring camp grazing impact & 9728 & 73402.4 & 105377.5 & \\
\hline Summer-autumn camp grazing impact & 15260 & 22132 & 46055 & 49225 \\
\hline Overlap of the winter-summer pasture & 17323 & & & \\
\hline Mining impact & 3658.83 & & & \\
\hline Settlement area impact & 3010 & 3849 & 5077 & 6272 \\
\hline Cropland impact & 17565.98 & & & \\
\hline Dirt road impact & 9739.4 & 25208.1 & 72612.1 & 22455.78 \\
\hline
\end{tabular}

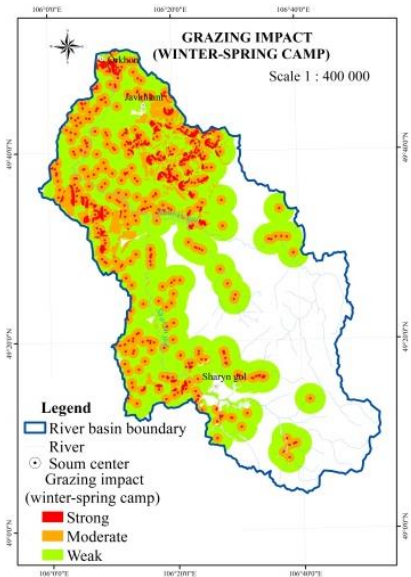

Figure 2. Grazing impact (winter-spring camp)

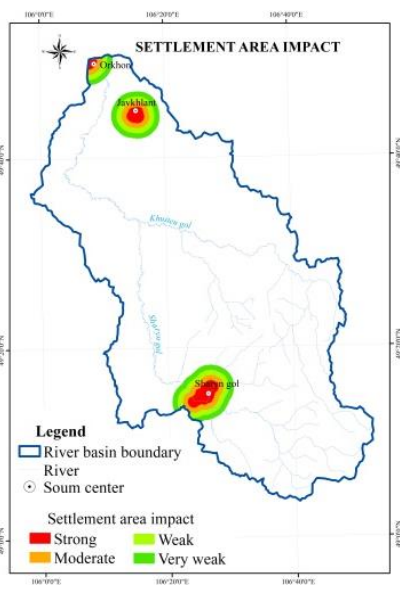

Figure 6. Settlement area impact

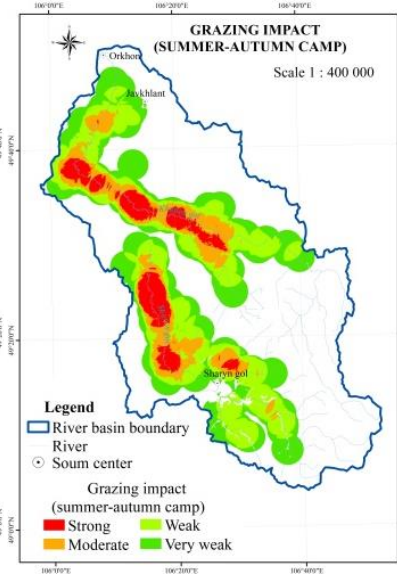

Figure 3. Grazing impact (summer-autumn camp)

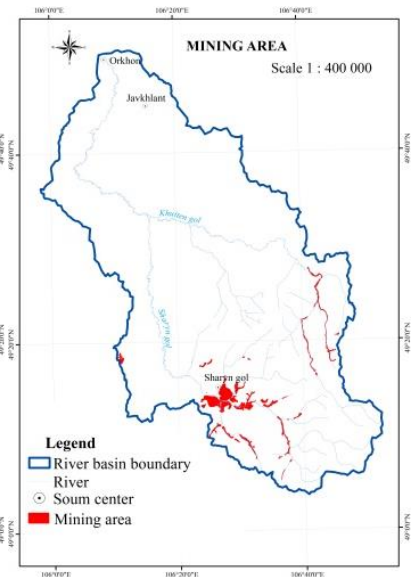

Figure 7. Mining area

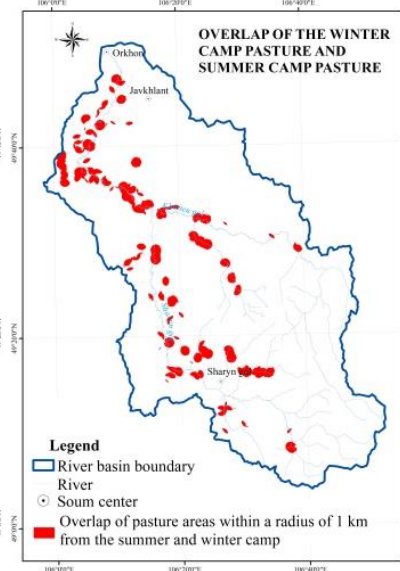

Figure 4. Overlap of the winter camp pasture and summer camp pasture

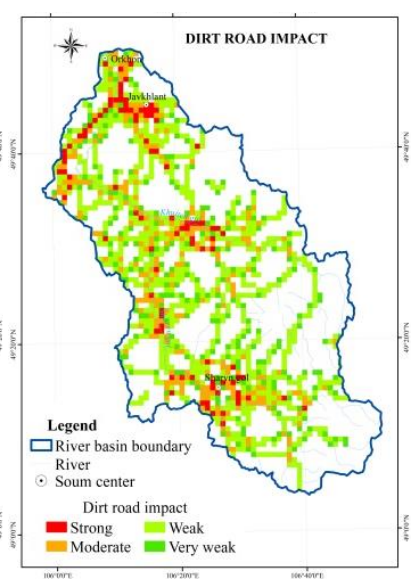

Figure 8. Dirt road impact

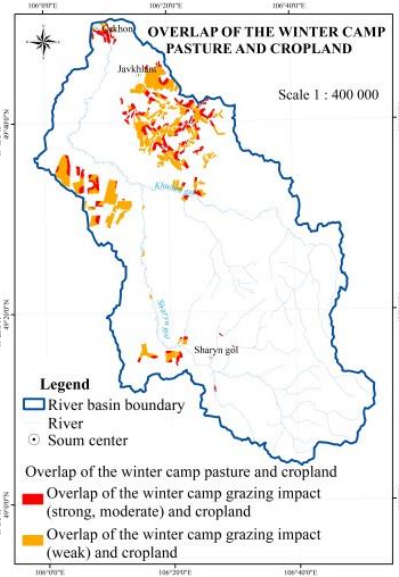

Figure 5. Overlap of the winter camp pasture and cropland 
In order to determine the spatial distribution of human activities in Sharyn Gol River Basin the land use type's impact estimation each layer was ranked and the weights were calculated using the Analytic hierarchy process. Based on Avirmed et al., [7], land use patterns are ranked according to their environmental impact as follows (Table 4).

Table 4. Ranking and weighing of human activity impact assessment criteria

\begin{tabular}{|l|l|l|}
\hline Indicator & Rank & $\begin{array}{l}\text { Weighed } \\
\text { value }\end{array}$ \\
\hline Mining impact (M) & 1 & 0.3767 \\
\hline Soum center impact (S) & 2 & 0.2431 \\
\hline Cropland impact (C) & 3 & 0.1501 \\
\hline Pasture use impact (P) & 4 & 0.0880 \\
\hline Dirt road impact (R) & 5 & 0.0541 \\
\hline Consistency ratio (CR): 0.0116 \\
\hline
\end{tabular}

According to the human impact assessment, $1.4 \%$ or 4267.23 ha of Sharyn Gol River Basin determined severely, $6.9 \%$ or 20396.33 ha strong, $18.7 \%$ or 55148.35 ha moderate, $33 \%$ or 97060.18 ha weak, and $39.9 \%$ or 117489.57 ha very weak (Figure 9 ).

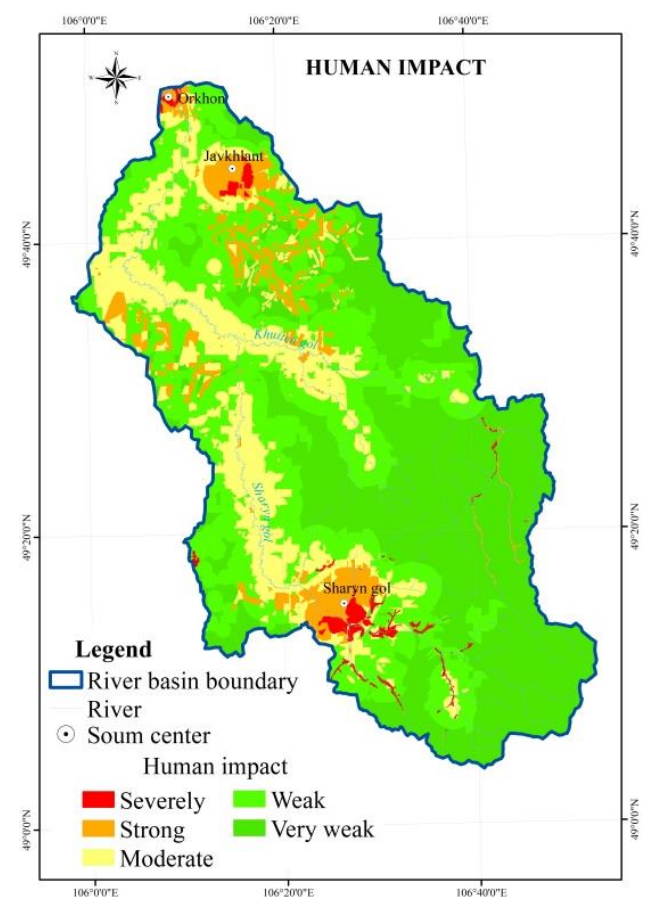

Figure 9. Human activity impact in Sharyn Gol River Basin

By studying and summarizing the impact factors of human activities in a specific space it is possible to determine the impact of human activities in terms of spatial analysis and assess the impact of land degradation. It's easier to assess land use in spatial concept in the context of pastoral country [8]. The impact of human activities assessed by the density of herder households per unit area based on the seasonal location of herder households at the regional, and province level $[8 ; 10 ; 11]$. In order to determine the impact of pasture use with detailed spatial accuracy, we considered the impact of winter-spring land by distance from winter camp, summer-spring lands by the overlap of herder households' pasture use, year around used area considered to be winter-summer pastures overlapps. The overlap of pasture use of herder households estimated for this study however, livestock per unit of overlapping pasture not estimated. In the future, the number, type, density, and carrying capacity of herder households should be estimated when selecting pasture use overlaps as criteria for assessing the impact of pasture use.

The impact of mining is considered in the context of the operating mining area. Although the size of the mine site is small compared to the total area of the administrative unit but the environmental impact is not limited to the mine site. Therefore, more detailed research data required to identify and assess the spatial distribution of mining impacts.

Researchers created a buffer zone on both sides of the road $[7 ; 8]$ and the road density per unit area with a radius of $2.7 \mathrm{~km} \mathrm{[11],} \mathrm{using} \mathrm{the} \mathrm{impact} \mathrm{reduction}$ function [15] depending on the type of road and the intensity of the usage. We calculated the road impact only in terms of the density per $1 \mathrm{~km}^{2}$ of unpaved road. There is a need to develop a methodology for assessing and summarizing the impact of the main vertical road, paved roads connecting soum centers with the main vertical road, railways, improved unpaved roads and unpaved roads in the future to fully assess the impact of the road.

This study on assessing the human impact activities in Sharyn Gol River Basin not fully covers all types of human activities in the basin. For example, impacts related to recreation and forestry activities not considered. Thus, some areas may be affected by more human activities than what we have identified.

\section{CONCLUSIONS}

The Human Footprint method developed by Sanderson et al., [16] was used to assess and map the human activities impact in the Sharyn Gol River Basin. Seven indicators (grazing impacts of winter-spring and summer-autumn camp, overlap of the winter camp and summer camp pasture, settlement area, mining area, crop land and dirt road) selected to determine the spatial distribution and its degree of human activities. The weight values of each indicator were calculated using the GIS based MCDA and AHP method to assess the human activities impact. Our research result shows that $1.4 \%$ is severely, $6.9 \%$ is strong, $18.7 \%$ is moderate, $33 \%$ is weak, and $39.9 \%$ is very weak impacted in Sharyn Gol River Basin. According to the impact assessment for each indicator following impacts 
determined: 188507.9 ha of winter-spring pasture area, 132673 ha of summer-autumn pasture area, 18208 ha of settlement area, 3658 ha of mining, 130015.38 ha of dirt road, and 17565.98 ha of cropland respectively. The most affected areas' which covers the largest area are winter-spring pasture, summer-autumn pasture and dirt roads. In terms of the severity, cropland has the largest area of strong impact, while the winter-spring pasture use has the highest area from moderate to low impact. Considering the spatial distribution of human activities impact are high in settlement area with high density of dirt roads, mining areas, agricultural lands, and pasture along the river. Particularly, human activities impact determined at severe degree in Orkhon and Javkhlant soum centers' dirt road, crop land and settlement area overlaps and in Sharyn gol soum center's mining and dirt road overlaps.

\section{ACKNOWLEDGMENTS}

The authors would like to acknowledge our colleagues of the Water resource and Water utilization division, Institute of Geography and Geoecology, Mongolian Academy of Sciences for their valuable and helpful comments and suggestions. We are specifically thankful to Ph.D Davaajargal Boldbaatar for his support, valuable comments and suggestions.

\section{REFERENCES}

[1] Dorjgotov, D., Enkhtaivan, D., Oyungerel, B., Avirmed, E., Renchinmyadag, T., Narangerel, S., Munkhdulam, O., Sukhbaatar, J., Tungalag, E., Odbaatar, E. \& Battushig, B. (2013). "Physical and socio-economic geographical comprehensive description and database of the central region of Mongolia" (2011-2013) scientific research report. Institute of Geography, MAS. Ulaanbaatar. pp. 4. (in Mongolia)

[2] Duan, Q., Luo, L., Zhao, W., Zhuang, Y. \& Liu, F. (2021). Mapping and Evaluating Human Pressure Changes in the Qilian Mountains. Remote Sensing 13, no.12: pp. 2400. https://doi.org/10.3390/rs13122400.

[3] Venter, O., Sanderson, E.W., Magrach, A., Allan, J.R., Beher, J., Jones, K.R., Possingham, H.P., Laurance, W.F., Wood, P., Fekete, B.M., Levy, M.A. \& Watson, J.E.M. (2016). Sixteen years of change in the global terrestrial human footprint and implications for biodiversity conservation. Nature Communications 7, 12558 (2016). pp. 1-9. https://doi.org/10.1038/ncomms12558-18

[4] Haines, A.M., Leu, M., Svancara, L.K., Scott, J.M. \& Reese, K.P. (2008). A theoretical approach to using human footprint data to assess landscape level conservation efforts. Conservation Letters 1
(2008). pp.165-172. https://doi.org/10.1111/j.1755263X.2008.00024.X

[5] Tucker, M.A., Böhning-Gaese, K., Fagan, W.F., Fryxell, J.M., Moorter, B.V., Alberts, S.C., Ali, A.H., Allen, A.M., Attias, N., Avgar, T., BartlamBrooks, H., Bayarbaatar, B., Belant, J.L., Bertassoni, A., Beyer, D., Bidner, L., van Beest, F.M., Blake, S., Blaum, N., Bracis, C., Brown, D., Nico de Bruyn, P.J., Cagnacci, F., Calabrese, J.M., Camilo-Alves, C., Chamaillé-Jammes, S., Chiaradia, A., Davidson, S.C., Dennis, T., DeStefano, S., Diefenbach, D., Douglas-Hamilton, I., Fennessy, J., Fichtel, C., Fiedler, W., Fischer, C., Fischhoff, I., Fleming, C.H., Ford, A.T., Fritz1, S.A., Gehr, B., Goheen, J.R., Gurarie, E., Hebblewhite, M., Heurich, M., Hewison, A.J.M., Hof1, C., Hurme, E., Isbell, L.A., Janssen, R., Jeltsch, F., Kaczensky, P Kane, A., Kappeler, P.M., Kauffman, M., Kays, R., Kimuyu, D., Koch, F., Kranstauber, B., LaPoint, S., Leimgruber, P., Linnell, J.D.C., López-López, P., Markham, A.C., Mattisson, J., Medici, E.P., Mellone, U., Merrill, E., de Miranda Mourão, G, Morato, R.G., Morellet, N., Morrison, T.A., Díaz-Muñoz, S.L., Mysterud, A., Nandintsetseg, D., Nathan, R., Niamir1, A., Odden, J., O'Hara1, R.B., Oliveira-Santos, L.G.R., Olson, K.A., Patterson, B.D, Cunha de Paula, R.C., Pedrotti, L., Reineking, B., Rimmler, M., Rogers, T.L., Rolandsen, C.M., Rosenberry, C.S, Rubenstein, D.I., Safi, K., Saïd, S., Sapir, N., Sawyer, H., Schmidt, N.M., Selva, N., Sergie, A., Shiilegdamba, E., Silva, J.P., Singh, N., Solberg, E.J., Spiegel, O., Strand, O., Sundaresan, S., Ullmann, W., Voigt, U., Wall, J, Wattles, D., Wikelski, M., Wilmers, C.C, Wilson, J.W., Wittemyer, G., Zięba, F., Zwijacz-Kozica, T. \& Mueller.T. (2018). Moving in the Anthropocene: Global reductions in terrestrial mammalian movements. Science. Vol. 359, issue 6374. pp. 466469. DOI: $10.1126 /$ science.aam 9712

[6] Marco, M.D., Venter, O., Possingham, H.P. \& Watson, J.E.M. (2018). Changes in human footprint drive changes in species extinction risk. Nature Communications 9 (2018). pp. 4621 https://doi.org/10.1038/s41467-018-07049-5

[7] Avirmed, E., Oyungerel, B., Renchinmyadag, T., Munkhdulam, O., Bayanjargal, B., Batnyam, Ts., Davaagatan, T., Purevsuren, M., Erdenesukh, S., Davaadorj, D., Sersmaa, J. \& Dorjnamjaa, D. (2020). Landscape ecological potential of Mongolia. Ulaanbaatar. Publishing house "Namnan design”, pp.73-81, 283. (in Mongolia)

[8] Sainbayar, D., Erdenesukh, S., Munkhhuyag, A. \& Boldbaatar, A. (2019). To estimate the human and climate impact in land degradation. In: Proceeding of the 4th International Conference on "Natural 
condition and territorial location aspects influencing in socio-economic development". Ulaanbaatar. pp. 382-389. (in Mongolia)

[9] Dalantai, S., Sumiya, E., Bao, Y., Otgonbayar, M., Mandakh, U., Batsaikhan, B. \& Natsagdorj, B. (2021). Spatial-temporal changes of land degradation caused by natural and human induced factors: Case study of Bulgan province in central Mongolia. Int. Arch. Photogramm. Remote Sens. Spatial Inf. Sci., XLIII-B4-2021. pp.79-85. https://doi.org/10.5194/isprs-archives-XLIII-B42021-79-2021

[10]Hainer, M., Galbadrakh, D., Kiesecker, J., McKenney, B., Evans, J., Tuguldur, E., Zumberelmaa, D., Ulziisaikhan, V., Oyungerel, B., Sanjmyatav, D., Ganhuyag, R., Enkhbat, D., Ochirkhuyag, L., Sergelen, G., Girvetz, E. \& McDonald, R. (2011). Identifying conservation priorities in the face of future development: Applying development by design in the grasslands of Mongolia. In: The Nature Conservancy. Ulaanbaatar. pp. 25. https://www.nature.org/media/smartdevelopment/mongolia-grasslands-development-bydesign.pdf

[11] Hainer, M., Yunden, B., Kiesecker, J., Davaa, G., Nyamsuren, B., Ganbaatar, M., Ichinkhorloo, O., Oidov, E., Dochinbuu, E., von Wehrden, H., Reading, R., Olson, K., Jackson, R., Evans, J., McKenney, B., Oakleaf, J. \& Sochi.K. (2013). Identifying conservation priorities in the face of future development: Applying development by design in the Mongolian Gobi. In: Batsaikhan. N, Adiya. Ya, Amgalan. L, Amgalanbaatar. S, Ariungerel. D, Dash. D, Lkhagvasuren. B, Munkhtsog. B, Oyungerel. B, Sanjmyatav. D, Suran. D, Terbish. Kh, Tseveenmyadag. N, Tsogtjargal. G, Zumberelmaa. D. (Eds.). The Nature Conservancy. Ulaanbaatar. pp. 27-30. https://www.nature.org/media/smartdevelopment/development-by-design-gobienglish.pdf

[12] Gunin, P.D., Vostokova, E.A., Bazha, S.N., Bayasgalan, D., Dorofeyuk, N.I., Drobyshev, Yu.I., Dugarjav, Ch., Miklyaeva, I.M., Prischepa, A.V., Cherdonova, V.A., Tsedendash, G. \& Shvetsov, Yu.G. (2005). The ecosystems of Selenga basin. Moscow. Academic publishing house "Nauka", pp. 198. (in Russian)

[13] Sainbuyan, S., Khugjilt, J., Urtnasan, M., Narangerel, B., Narantsatsral, Ts., Sainbayar, D. \& Enkhjargal, D. (2017). The issues for pasture use. In: Dorjgotov. D, Amarsaikhan. D, Avirmed. E, Odontsetseg. D, Javzan. Ch, Nyamdavaa. B, Udval.B, Tsendsuren. D, Saulegul. A, Urtnasan. M. (Eds.), Geography and Geoecological issue in Mongolia. Special edition. Ulaanbaatar. pp. 169185. (in Mongolia)

[14] Institute of Biology. (1998). "Orkhon-Selenge river basin's ecosystem's ecology and biology assessment and its restoration basis" (1996-1998) scientific research report. Joint Russian-Mongolian complex Biological Expedition. Institute of Biology, MAS. Ulaanbaatar, Moscow. pp.42-51. (in Mongolia)

[15] Davaajargal, B. \& Badarch, Kh. (2020). Impact assessment of land use change in the Shariin-gol basin. In: Environment and Sustainable Development of the Mongolian Plateau and Surrounding Territories. XIII International Conference Proceedings 2020. pp. 99-104.

[16] Sanderson, E.W., Jaiteh, M., Levy, M.A., Redford, K.H., Wannebo, A.V. \& Woolmer, G. (2002). The Human Footprint and the Last of the Wild. BioScience, vol. 52, issue 10. pp. 891-904. https://doi.org/10.1641/00063568(2002)052[0891:THFATL]2.0.CO;2 